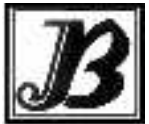

J. bio-sci. 21: 89-98, 2013

ISSN 1023-8654

http://www.banglajol.info/index.php/JBS/index

\title{
DEVELOPMENT OF CAPTIVE JUVENILE MALE GRASSCUTTERS (THRYONOMYS SWINDERIANUS. TEMMINCK 1827) FED WITH TWO COMMON FORAGE GRASS SPECIES IN NIGERIA
}

\author{
Ogunjobi ${ }^{*}$ JA, ${ }^{1}$ Adu BW, ${ }^{2}$ Onadeko, S A, ${ }^{2}$ Jayeola OB \\ 1Department of Biological Sciences, Ondo State University of Science and Technology, \\ Okitipupa, Ondo State, Nigeria \\ ${ }^{2}$ Department of Forestry and Wildlife Management, Federal University of Agriculture, \\ Abeokuta, Ogun State, Nigeria
}

\begin{abstract}
Context: Sustainable utilization of abundant forage grass species in Nigeria is very crucial in grasscutter domestication programme.

Objective: This study evaluates comparative effects of Elephant grass (Pennisetum purpureum) and Gamba grass (Andropogon gayanus) parts on growth performance of captive-bred juvenile male grasscutters

Materials and Methods: The study was conducted inside Grasscutter Domestication Unit of Federal College of Wildlife Management, New Bussa, Niger State, Nigeria. The experimental animal comprised of twenty-four juvenile males (JM) with mean live-weight of $410 \pm 2.11 \mathrm{~g}$ fed four basal dietary treatment combinations: Elephant grass stem (EGS), Elephant Grass Leaf (EGL), Gamba Grass Stem (GGS) and Gamba Grass Leaf (GGL) in a $2 \times 2$ factorial arrangement for 120 days to obtain data which includes feed intake (FI), feed conversion ratio (FCR), weight gain (WG), nutrient digestibilities of dry matter (DM) and crude fibre (CF).

Results: Average daily feed intake $(\mathrm{FI})$ in $\mathrm{JM}$ was significantly $(\mathrm{p}<0.05)$ higher in experimental animals fed with GGS (107.23g/d) and EGS (106.21g/d) relative to GGL (105.89g/d) and EGL (105.14g/d). EGL exhibited higher (4.45g/d) WG and lowest (23.69) FCR. JM fed EGL recorded highest digestibility of DM (85.64\%) and CF (83.84\%), respectively. Grass species and parts interaction showed significant variation $(p<0.05)$ on $\mathrm{FI}, \mathrm{DM}$ and $\mathrm{CF}$ of the animals when fed EGL.

Conclusion: It was evident that EGL was maximally utilized by captive-bred juvenile male grasscutters for growth performance hence, feeding of captive male grass cutters with EGL as basal food for table meat production is recommended.
\end{abstract}

Key words: Captivity, juvenile male grasscutters, growth performance. Introduction

Persistent indiscriminate collection of biological resources of either plant or animal origin in the developing countries particularly in the tropical region of the world continues to generate a lot of new idea and or innovation, perhaps due to it unselective consequences on human being which may be hazardous and uneconomical to abate. In recognition of these implication as well as threats to wild animal and their habitat by man, the idea of captive rearing of wild animals in form of ex-situ conservation in Africa to improve the quantities and quality of animal protein available to man and other non consumptive benefits enjoy by man was approached back 1884 (Surujbally 1975). Onadeko et al. (1998) informed that the capability of certain wildlife species to get around and multiply despite intensive hunting and its ability to associate with human habitations provide important feature for farm wildlife management. Odunaiya and Akinnusi (2008) however encouraged people to farm micro-livestock such as snail, bush fowl, giant rats, rabbits and grasscutters.

* Corresponding author E-mail: ogunjonson02@gmail.com 
Warwick (1987) extensively discussed the general behaviour of captive animals. Heath and Olusanya (1985) submitted that the economic traits considered in selecting animal for meat production includes reproductive performance, carcass quality, longevity, resistance to disease and growth rate. Although reproductive output is measured according to animal maturity, litter size and length of inter-birth, all the same nutrition is noticeable among other interactive factors that determine reproductive success in farm animal (Redford et al .1995, Ashworth 1994).

Ogunjobi (2008) suggested that with proper documentation concerning grasscutter reproductive performance and the survival rate of its litter's made known to practicing and prospective grasscutter farmers', the efforts will be rewarding and go a long way in improving low level of animal protein in-take of Nigerians. Earlier, National Research Council (NRC 1991) acknowledged that research on grasscutters husbandry, health and reproductive biology will assist in its successful domestication. The need for domestication of grasscutter in a man-made modified habitat for optimal performance will require good and adequate nutrition. Adequate nutrition will involve more than nutrient composition as it will also note the idiosyncrasies of the animal.

Nigeria forage grass according to Schmetzer (1996) is native to West Africa and was first introduced to India from where it has spread to South East Asia and North Australia. About 97\%t of Nigeria's ruminant animals are dependent on forage and fodder crops for their productivity and in fact forage and fodder crops are central to the development of Nigeria's livestock industry (Shiawoya and Tsado, 2011). This feed resource, which consists mainly of grasses, legumes, browses, and cereal crop residues vary widely and are spread across the major agro-ecological zones of the country ( Shiawoya and Tsado, 2011).

In Nigeria, captive grasscutters thrives on a diverse numbers of compounded concentrate and grassses. It is vital to investigate the effect of the commonly consumed grass by ex-situ grasscutters (i.e Elephant grass) in the rain-forest Nigeria reported (Ogunjobi et al. 2007) and the most available (i.e Gamba grass) in the guinea savanna Nigeria available to in-situ grasscutters (Meduna 2000) for effective captive-bred grass cutters sustainability that will meet public demand and improve animal protein in the diet of mankind. This study was conducted to evaluate the effect of elephant grass (Pennisetum purpureum) and gamba grass (Andropogon gayanus) parts on growth performance of captive- bred juvenile male grasscutters.

\section{Materials and Methods}

This study was carried-out at the Grasscutter Domestication Unit of the Federal College of Wildlife Management located within the College estate in the guinea savanna vegetation belt in Nigeria on latitude $7^{0} 08^{1}$ and $1^{0} 00^{1} \mathrm{~N}$ and longitude $4^{0} 30$ and $4^{0} 3^{1} \mathrm{E}$ in-between Kainji dam and New Bussa, Niger State (Ogunjinmi et al. 2007). Experimental grass cutter which comprised of twenty-four juvenile male with average live-weight of $410 \pm 2.11 \mathrm{~g}$ were housed inside $60 \mathrm{~cm} \times 50 \mathrm{~cm} \times 40 \mathrm{~cm}$ made of cement and brick materials with wooden door on top and studied for 120 days. Two grass species (elephant grass and gamba grass) and two parts (stem and leaf) to formed four treatment combinations namely elephant grass stem $\left(T_{1}\right)$, elephant grass leaf $\left(T_{2}\right)$, gamba grass stem $\left(T_{3}\right)$ and gamba grass leaf $\left(T_{4}\right)$ were used in this study. These basal diets were supplemented with concentrate containing $16 \%$ crude protein and $2500 \mathrm{Kcal} / \mathrm{kg}$ of Metabolizable energy. The chemical composition of the four dietary treatments and concentrate diet are shown on Tables 1 and 2 respectively. Experimental animal were assigned to these four dietary treatment combinations and replicated thrice ( 2 animals per replicate) in a $2 \times 2$ factorial arrangement. The experimental feeds were designed in such a way that captive production of grass cutters among practicing and potential farmers' can be affordable and sustained in Nigeria and in the countries of the world with similar ecological zone with Nigeria. 
The grasses (Pennisetum purpureum and Andropogon gayanus) stems and leaves used for this study were wilted overnight under the shade before they were fed on basal along with a compounded concentrate to the experimental grasscutter. Since captive grasscutters solely depends on the keeper for feeding and other management techniques, feeding was done twice in a day, the animal were served ad- libitum with basal diets between $9.30 \mathrm{a} . \mathrm{m}-10.30 \mathrm{a} . \mathrm{m}$ and fixed quantity ( $10 \%$ body weight) of concentrate between $2.00 \mathrm{p} . \mathrm{m}$ -3.00 p.m. Feeding of the experimental grasscutter complied with the guidelines provided by Ayodele and Meduna (2007).

The initial weights (IW) of each of the juvenile male grasscutters were taken at the start of the experiment using Camry Emperors top load scale (made in China). The final body weight (FBW) of the animals at the end of feeding trial were recorded and subtracted from the initial weight and divided by number of grasscutters for each replicate to obtain the average weight gain (WG).

Average body weight gain $(\mathrm{g})=$ Final weight $(\mathrm{g})-\operatorname{Initial}$ weight $(\mathrm{g})$

Total number of grasscutters

Average feed consumption (AFC) was obtained by taken the initial weights of the experimental feeds subtracted from the measured leftover collected after sorted out droppings. Water consumed followed the same format.

AFC $(\mathrm{g}) \quad=$ Initial weight of feeds offered $(\mathrm{g})$-Final weight of feeds leftover $(\mathrm{g})$

Total number of grasscutters

Feed intake ( $\mathrm{Fl})$ was calculated by subtracting leftover feed from the quantity given

Feed conversion ratio (FCR) was calculated by dividing weight gained (WG) by the feed intake. Feed conversion ratio $=\quad$ Feed intake $(\mathrm{g})$

Weight gained $(\mathrm{g})$

Table 1. Chemical composition of treatment combinations fed experimental grass cutters.

\begin{tabular}{lcccc}
\hline \multicolumn{1}{c}{ Parameters } & $\begin{array}{c}\text { Elephant grass } \\
\text { stem }\end{array}$ & Elephant grass leaf & Gamba grass stem & $\begin{array}{c}\text { Gamba grass } \\
\text { leaf }\end{array}$ \\
\hline Dry matter (\%) & 25.05 & 22.60 & 21.85 & 22.35 \\
Crude protein (\%) & 9.12 & 9.62 & 7.35 & 9.20 \\
Crude fibre (\%) & 23.20 & 20.40 & 24.20 & 21.95 \\
Ash (\%) & 12.60 & 13.44 & 12.20 & 11.39 \\
Ether extract (\%) & 1.75 & 1.90 & 1.80 & 1.79 \\
Neutral detergent fibre (\%) & 62.34 & 63.65 & 62.29 & 63.17 \\
Acid detergent fibre (\%) & 41.25 & 43.75 & 41.40 & 42.42 \\
Acid detergent lignin (\%) & 3.60 & 3.75 & 3.56 & 3.59 \\
Hemicelluloses (\%) & 21.09 & 20.90 & 20.89 & 20.75 \\
Calcium (\%) & 0.61 & 0.82 & 0.75 & 0.79 \\
Phosphorus (\%) & 0.45 & 0.48 & 0.41 & 0.46 \\
Metabolizable Energy (Kcal/kg) & 2355.57 & 2435.75 & 2337.47 & 2359.00 \\
& & & & \\
\hline
\end{tabular}


Table 2. Composition of supplementary concentrate diet fed experimental grass cutters.

\begin{tabular}{cc}
\hline Ingredients & Percentage inclusion (\%) \\
\hline Maize & 34.95 \\
Wheal offal & 32.00 \\
Palm kernel Cake (PKC) & 15.00 \\
Maize bran & 3.00 \\
Soybean meal & 12.50 \\
Fishmeal (75\%) & 1.00 \\
Oyster shell & 1.00 \\
Bone meal & 2.50 \\
Vitamin premix & 0.25 \\
Salt & 0.30 \\
Total & 100 \\
ME(Kcal/kg) & 2604.00 \\
Determined analysis & Percentage (\%) \\
Dry matter (DM) & 93.00 \\
Crude protein (CP) & 16.19 \\
Crude fibre (CF) & 6.27 \\
Ash & 4.18 \\
Ether extract (EE) & 7.35 \\
Calcium & 1.40 \\
Phosphorus & 0.61 \\
\hline & \\
\hline
\end{tabular}

Premix supplied per kg of feed: Vit. A 4,000,000iu, Vit. $D_{3} 6000,000 \mathrm{iu}$, Tocopherols 4000iu, Vit. $K_{1} 800 \mathrm{mg}$, Folacin 200mg, Copper 2000mg, lodine 480mg, Colbalt 80mg, Calcium Panthothenate 2000mg, Pyridoxine $600 \mathrm{mg}$, Cyanocolabamin $4.0 \mathrm{mg}$, Biotin 8mg, Thiamine 600 $\mathrm{mg}$, Riboflavin $1800 \mathrm{mg}$, Niacin $6000 \mathrm{mg}$, Manganese 30,000mg, Zinc 20,000 mg, Iron 8,000 mg, Choline chloride 80,000mg, Selenium 40mg, BHT 25,000mg, Anticaking agent 6000mg

Digestibility study was conducted in the last seven days in experiment. Weighed quantity of feed were given to the grasscutters while faecal droppings were collected, bulked according to the treatments and oven dried at $65^{\circ} \mathrm{C}$ for 48 hours. The chemical composition of the droppings and experimental feeds were analysed according to the procedure of A.O.A.C (1990) and the nutrient digestibility were calculated as follows:

Apparent nutrient digestibility $=$ Nutrient in feed intake - Nutrient in dropping $\times 100$ 
Data obtained from the study were subjected to statistical analysis by a $2 \times 2$ factorial arrangement according to the General Linear Model procedure of SAS (1999) and significant means were separated using Duncan's Multiple Range Test (Duncan 1955).

The model employed was:

$Y i j=\mu+A i+B j+(A B) i j+e i j$

Where $Y i j=$ Parameter of interest

$\mu=$ Overall means for the parameters of interest

$\mathrm{Ai}=$ Fixed effect of ith dietary treatment $(\mathrm{i}=$ elephant grass and gamba grass $)$

$\mathrm{Bj}=$ Fixed effect of $j$ th plant parts $(j=$ stem and leaf)

$(A B) i j=$ Combine interaction effect of dietary treatment and plant parts

$\mathrm{Eij}=$ Random error associated with each record (normally, independently and identically distributed with zero mean and variance).

\section{Results}

\section{Effect of grass species supplemented with concentrate on growth performance in juvenile males}

The effect of the elephant grass (EG) and gamba grass (GG) supplemented with concentrate on growth performance of juvenile male grasscutters (JMG) is presented in Table 3 revealed that the grass species had significant $(P<0.05)$ effect on the average total weight gain $(W G)$ and average feed intake $(F I)$. JMG fed with elephant grass had the higher average total WG $(532 \mathrm{~g})$, lower average daily FI $(99.76 \mathrm{~g} / \mathrm{d})$, feed conversion ratio (22.52). Average daily WG was higher (4.43g/d) in JMG fed with EG compared with $4.41 \mathrm{~g} / \mathrm{d}$ obtained when the animal are fed with $\mathrm{GG}$.

\section{Effect of grass parts supplemented with concentrate on growth performance in juvenile males}

Table 4 shows the effect of stems and leaves of the two grass species supplemented with concentrate on growth performance in juvenile male grasscutters $(J M G)$. Significant $(P<0.05)$ variation was recorded on the weight gain (WG), and average daily feed intake (FI). JMG fed with the grass leaves had better performance in terms of average total WG $(531.00 \mathrm{~g})$, lower daily FI $(98.96 \mathrm{~g} / \mathrm{d})$ and feed conversion ratio (22.34). Average daily weight gain was higher (4.43g/d) in JMG fed with grass leaves compared to $4.42 \mathrm{~g} / \mathrm{d}$ in JMG fed with stems part.

Interaction effect of grass species and parts supplemented with concentrate on growth performance in juvenile males

Growth performance of juvenile male grasscutters (JMG) as influenced by the interaction between elephant grass stem (EGS), elephant grass leaf (EGL), gamba grass stem (GGS) and gamba grass leaf (GGL) and supplemented with concentrate is presented in Table 5 . The grass species and grass parts interaction showed significant $(P<0.05)$ effect in the weight gain $(W G)$, feed intake $(F I)$ and mortality $(M R)$ while feed conversion ratio (FRC) was not significantly $(P>0.05)$ affected. Average WG $(939.00 \mathrm{~g})$ was higher in JMG fed with EG leaf inclusion compared to lowest value (935.17g) obtained when fed with stem inclusion. The lowest average FI (105.14g/d) and FCR (22.50) were from the JMG fed with EGL. The average daily weight gain of $4.41 \mathrm{~g} / \mathrm{d}, 4.45 \mathrm{~g} / \mathrm{d}, 4.40 \mathrm{~g} / \mathrm{d}$ and $4.43 \mathrm{~g} / \mathrm{d}$ were recorded in EGS, EGL, GGS and $\mathrm{GGL}$, respectively. Generally, the growth performance of the JMG was better when fed with EGL. 
Table 3. Effect of grass species supplemented with concentrate on growth performance in juvenile male grass cutters

\begin{tabular}{lcc}
\hline Parameters & Elephant grass \pm SEM & Gamba grass \pm SEM \\
& $\mathrm{N}=12$ & $\mathrm{~N}=12$ \\
\hline Average initial weight $(\mathrm{g})$ & $406.42 \pm 0.60$ & $406.50 \pm 0.54$ \\
Average final weight $(\mathrm{g})$ & $938.42 \pm 1.89^{\mathrm{a}}$ & $934.75 \pm 1.80^{\mathrm{b}}$ \\
Average total body weight gain $(\mathrm{g})$ & $532.00 \pm 2.10^{\mathrm{a}}$ & $529.08 \pm 1.98^{\mathrm{b}}$ \\
Average daily body weight gain $(\mathrm{g} / \mathrm{d})$ & $4.43 \pm 0.01$ & $4.41 \pm 0.01$ \\
Average total feed intake $(\mathrm{g} / \mathrm{d})$ & $99.76 \pm 0.77^{\mathrm{b}}$ & $101.09 \pm 0.82^{\mathrm{a}}$ \\
Feed conversion ratio & $22.52 \pm 0.06$ & $22.92 \pm 0.08$ \\
Mortality (\%) & 0.00 & 0.00 \\
\hline
\end{tabular}

$a, b$ means with different superscripts along the same row differ significantly $(p<0.05)$

Table 4. Effect of grass parts supplemented with concentrate on growth performance in juvenile male grass cutters

\begin{tabular}{lcc}
\hline Parameters & Grass stems \pm SEM & Grass leaves \pm SEM \\
& $\mathrm{N}=12$ & $\mathrm{~N}=12$ \\
\hline Average initial weight $(\mathrm{g})$ & $406.33 \pm 0.60$ & $406.58 \pm 0.72$ \\
Average final weight $(\mathrm{g})$ & $936.83 \pm 1.89^{\mathrm{ab}}$ & $937.58 \pm 1.94^{\mathrm{a}}$ \\
Average total body weight gain $(\mathrm{g})$ & $530.50 \pm 2.10^{\mathrm{ab}}$ & $531.00 \pm 2.80^{\mathrm{a}}$ \\
Average daily body weight gain $(\mathrm{g} / \mathrm{d})$ & $4.42 \pm 0.01$ & $4.43 \pm 0.01$ \\
Average total feed intake $(\mathrm{g} / \mathrm{d})$ & $100.09 \pm 0.77^{\mathrm{a}}$ & $98.96 \pm 0.68^{\mathrm{b}}$ \\
Feed conversion ratio & $22.64 \pm 0.02$ & $22.34 \pm 0.01$ \\
Mortality (\%) & 0.00 & 0.00 \\
\hline
\end{tabular}

$a, b$ means with different superscripts along the same row differ significantly $(p<0.05)$

Table 5. Interaction effect of grass species and parts supplemented with concentrate on growth performance in juvenile male grasscutters

\begin{tabular}{lcccc}
\hline Parameters & $\begin{array}{c}\text { Elephant grass } \\
\text { stem } \pm \text { SEM } \\
\mathrm{N}=12\end{array}$ & $\begin{array}{c}\text { Elephant grass } \\
\text { leaf } \pm \text { SEM } \\
\mathrm{N}=12\end{array}$ & $\begin{array}{c}\text { Gamba grass } \\
\text { stem } \pm \text { SEM } \\
\mathrm{N}=12\end{array}$ & $\begin{array}{c}\text { Gamba grass } \\
\text { leaf } \pm \text { SEM }\end{array}$ \\
\hline Average initial weight $(\mathrm{g})$ & $406.33 \pm 0.84$ & $406.50 \pm 0.86$ & $406.33 \pm 0.74$ & $406.67 \pm 0.89$ \\
& $935.17 \pm 2.68^{\mathrm{c}}$ & $939.00 \pm 2.70$ & $934.33 \pm 2.65$ & $937.83 \pm 2.61$ \\
Average final weight $(\mathrm{g})$ & $528.84 \pm 2.97^{\mathrm{c}}$ & $532.50 \pm 2.71^{\mathrm{a}}$ & $528.00 \pm 2.90^{\text {cd }}$ & $531.16 \pm 3.20^{\mathrm{b}}$ \\
$\begin{array}{l}\text { Average total body weight gain } \\
\text { (g) }\end{array}$ & $4.41 \pm 0.03$ & $4.45 \pm 0.07$ & $4.40 \pm 0.09$ & $4.43 \pm 0.06$ \\
$\begin{array}{l}\text { Average daily body weight gain } \\
\text { g/d) }\end{array}$ & $106.21 \pm 1.09^{\mathrm{ab}}$ & $105.14 \pm 1.01^{\mathrm{bc}}$ & $107.23 \pm 1.21^{\mathrm{a}}$ & $105.89 \pm 1.08^{\mathrm{b}}$ \\
$\begin{array}{l}\text { Average total feed intake (g/d) } \\
\text { Feed conversion ratio }\end{array}$ & $24.08 \pm 0.04$ & $23.63 \pm 0.01$ & $24.37 \pm 0.05$ & $23.90 \pm 0.04$ \\
Mortality (\%) & 0.00 & 0.00 & 0.00 & 0.00 \\
\hline
\end{tabular}

$a, b, c$ means with different superscripts along the same row differ significantly $(p<0.05)$ 


\section{Effect of grass species supplemented with concentrate on nutrient digestibility in juvenile males}

Presented in Table 6 is the main effect of elephant grass (EG) and gamba grass (GG) supplemented with concentrate on nutrient digestibility in juvenile male grasscutters (JMG). Digestibilities of dry matter (83.95 $\pm 0.72 \%)$, crude protein $(83.47 \pm 0.78 \%)$ and crude fibre $(82.74 \pm 0.40 \%)$ were significantly $(P<0.05)$ higher in JMG fed with EG while digestibilities of ash and ether extract of juvenile males $(80.91 \pm 0.20 \%$ and $64.40 \pm 0.11 \%$ ) fed elephant grass compared with $80.89 \pm 0.18 \%$ and $64.39 \pm 0.09 \%$ when fed with gamba grass were not significantly $(P>0.05)$ affected.

\section{Effect of grass parts supplemented with concentrate on nutrient digestibility in juvenile males}

Effect of stems and leaves of the two grass species supplemented with concentrate on juvenile male grasscutters (JMG) nutrient digestibility is presented in Table 7. JMG fed grass leaves showed significant $(P<0.05)$ higher values in digestibilities of dry matter $(83.02 \pm 0.95 \%)$, crude protein $(82.27 \pm 0.82 \%)$ and crude fibre $(80.63 \pm 0.35 \%)$ relative to $80.75 \pm 0.72 \%, 80.67 \pm 0.78 \%$ and $82.49 \pm 0.40 \%$ obtained when fed with the grass stems. Digestibilities of ash and ether extract irrespective of the grass parts was similar $(p>0.05)$.

Table 6. Effect of grass species supplemented with concentrate on nutrient digestibility in juvenile male grass cutters

\begin{tabular}{lcc}
\hline Parameters & Elephant grass \pm SEM & Gamba grass \pm SEM \\
& $\mathrm{N}=12$ & $\mathrm{~N}=12$ \\
\hline Dry matter (\%) & $83.95 \pm 0.72^{\mathrm{a}}$ & $82.82 \pm 0.45^{\mathrm{ab}}$ \\
Crude protein (\%) & $83.47 \pm 0.78^{\mathrm{a}}$ & $81.47 \pm 0.60^{\mathrm{b}}$ \\
Crude fibre (\%) & $82.74 \pm 0.40^{\mathrm{a}}$ & $80.39 \pm 0.37^{\mathrm{b}}$ \\
Ash (\%) & $80.91 \pm 0.20$ & $80.89 \pm 0.18$ \\
Ether extract (\%) & $64.40 \pm 0.11$ & $64.39 \pm 0.09$ \\
\hline
\end{tabular}

$a, b$ means with different superscripts along the same row differ significantly $(p<0.05)$

Table 7. Effect of grass parts on nutrient digestibility in juvenile male grass cutters

\begin{tabular}{lcc}
\hline Parameters & $\begin{array}{c}\text { Grass stems } \pm \text { SEM } \\
\mathrm{N}=12\end{array}$ & $\begin{array}{c}\text { Grass leaves } \pm \text { SEM } \\
\mathrm{N}=12\end{array}$ \\
\hline Dry matter (\%) & $80.75 \pm 0.72^{\mathrm{b}}$ & $83.02 \pm 0.95^{\mathrm{a}}$ \\
Crude protein (\%) & $80.67 \pm 0.78^{\mathrm{b}}$ & $82.27 \pm 0.82^{\mathrm{a}}$ \\
Crude fibre (\%) & $82.49 \pm 0.40^{\mathrm{a}}$ & $80.63 \pm 0.35^{\mathrm{b}}$ \\
Ash (\%) & $80.48 \pm 0.20$ & $80.31 \pm 0.19$ \\
Ether extract (\%) & $64.47 \pm 0.11$ & $64.33 \pm 0.10$ \\
\hline
\end{tabular}

a,b means with different superscripts along the same row differ significantly $(p<0.05)$

Interaction effect of grass species and parts supplemented with concentrate on nutrient digestibility in juvenile males

Table 8 shows the interaction effect of elephant grass stem (EGS), elephant grass leaf (EGL), gamba grass stem (GGS) and gamba grass leaf (GGL) supplemented with concentrate on nutrient digestibility of juvenile male grasscutters (JMG). Digestibilities of dry matter $(85.64 \pm 1.25 \%)$, crude protein $(83.86 \pm 1.19 \%)$ and crude fibre $(83.84 \pm 0.70 \%)$ were significantly $(P<0.05)$ higher among JMG fed with elephant grass leaf 
followed by $83.78 \pm 1.10 \%, 82.50 \pm 1.18 \%$ and $83.33 \pm 0.71 \%$ when fed with GGL while least values of $81.85 \pm 1.09 \%, 81.18 \pm 1.17 \%$ and $81.14 \pm 0.69 \%$ were obtained when fed with GGS. Digestibilities of ash and ether extract showed no significant different $(P>0.05)$ across the dietary treatment combinations. The nutrient digestibility performance in JMG showed better performance among the animals fed with EGL followed by GGL.

Table 8. Interaction effect of grass species and parts supplemented with concentrate on nutrient digestibility in juvenile male grass cutters

\begin{tabular}{lcccc}
\hline Parameters & $\begin{array}{c}\text { Elephant grass } \\
\text { stem } \pm \text { SEM } \\
\mathrm{N}=12\end{array}$ & $\begin{array}{c}\text { Elephant } \\
\text { leaf } \pm \text { SEM } \\
\mathrm{N}=12\end{array}$ & $\begin{array}{c}\text { grass } \\
\text { stem } \pm \text { SEM } \\
\mathrm{N}=12\end{array}$ & $\begin{array}{c}\text { Gamba grass } \\
\mathrm{N}=12\end{array}$ \\
\hline Dry matter (\%) & $82.25 \pm 1.02^{\mathrm{bc}}$ & $85.64 \pm 1.25^{\mathrm{a}}$ & $81.85 \pm 1.09^{\mathrm{c}}$ & $83.78 \pm 1.10^{\mathrm{b}}$ \\
Crude protein (\%) & $81.77 \pm 1.10^{\mathrm{b}}$ & $83.86 \pm 1.19^{\mathrm{a}}$ & $81.18 \pm 1.17^{\mathrm{bc}}$ & $82.50 \pm 1.18^{\mathrm{ab}}$ \\
Crude fibre (\%) & $81.93 \pm 0.56^{\mathrm{b}}$ & $83.84 \pm 0.70^{\mathrm{a}}$ & $81.14 \pm 0.69 \mathrm{~b}$ & $83.33 \pm 0.71^{\mathrm{a}}$ \\
Ash (\%) & $80.64 \pm 0.28$ & $80.45 \pm 0.19$ & $80.32 \pm 0.20$ & $80.18 \pm 0.18$ \\
Ether extract (\%) & $64.47 \pm 0.15$ & $64.34 \pm 0.13$ & $64.46 \pm 0.14$ & $64.31 \pm 0.14$ \\
\hline
\end{tabular}

$a, b, c$ means with different superscripts along the same row differ significantly $(p<0.05)$

\section{Discussion}

The type of response that may be expected from variation in the grass species and its parts when offered to captive-bred juvenile male grass cutters have been seen largely demonstrated by the results of this study. Average total body weight gain in this study which ranged from $528.00 \pm 2.90$ to $532.50 \pm 2.71 \mathrm{~g}$ was slightly lower than the value reported by Onadeko (1996), nevertheless the pattern of this study agreed with the finding of Onadeko (1996) that male grass cutters gained more weight compared with female counterpart.

The growth performance of juvenile grass cutters fed with leaves of the grass species confirmed that grass species and parts have important roles in animal body growth. This observation was similar to the findings of Annor et al. (2008). The effect of the elephant grass especially its leaf on weight gain in both juvenile male and female grass cutters suggested that this grass part was above maintenance level.

Relatively lower growth rate recorded among grass cutters fed with stem of the grass species compared to those fed with grass leaf may be attributed to the low nutritional composition of this plant part which is similar to the findings of Annor et al. (2008) that leafiness in pasture plants is commonly associated with forage quality.

Feed intake in this study contradicted the findings of Annor et al. (2009) when they submitted that grass cutters fed with of guinea grass had lower feed intake compared to those fed with the leaf part. This may be connected with Baumont et al. (2000) report that some physical characteristics of the forage, such as dry matter content and particle size are known to affect ease of prehension and thus intake rate and supported by Annor et al. (2008) which stated that the crude fibre and crude protein levels of diets may limit feed intake. Adeniji (2008) informed that lower Metabolizable energy could also lead to increase feed intake.

Akinnusi (2001) submitted that protein content of feed can influenced its intake by animal. In another related report, Minson (1982) accounted that the higher the water content of pasture, the lower the daily feed intake and hence energy consumed. Hurwitz et al. (1987) observed that changes in dietary energy concentration modulate feed efficiency: firstly as dietary energy increase, energy need are satisfied with decrease feed 
intake, and secondly growth rate is promoted by increasing dietary level. Feed conversion ratio obtained in this present study which ranged from $23.63 \pm 0.01$ to $24.37 \pm 0.05$ compared with the values obtained by Annor et al. (2008). This can be attributed to the availability of concentrate diet, different in the experimental feeds source and initial weight of the experimental animals in the present study. The overall feed efficiency showed that the juvenile grass cutters fed with elephant grass leaf were most efficient in feed conversion.

Nutrient digestibilities were generally higher among the juvenile grass cutters fed with leafy parts of the grass species. Data on nutrient digestibility of the juvenile grass cutters showed significant differences in the dry matter digestibility, crude protein digestibility and crude fibre digestibility. The values obtained were higher and better compared with the report of Obi et al. (2006) and similar to Onadeko (1996) findings on grass cutter fed high plane feed treatment, in line with, Karikari and Nyameasem (2009). One can say emphatically that the leafy part is more utilized. Higher values obtained in the present study especially among grass cutters fed with elephant grass leaf may not be unconnected with the submission of Adeniji (2009) that low dietary fibre in this feed treatment may be responsible even as Onwudike (1986) reported that increased crude fibre content of a diet reduced feed efficiency.

In conclusion, it was evident that EGL was maximally utilized by juvenile male grass cutters in captivity for growth performance hence, feeding of the animal with EGL as basal food for table meat production in Nigeria and similar ecological zones of the world is recommended.

\section{Acknowlegements}

The authors sincerely acknowledge the management of Federal College of Wildlife Management, Forestry Research Institute of Nigeria for the technical support provided during this research work.

\section{References}

Adeniji AA. 2009. Protein and energy requirements of weaner grass cutters. Animal Nutrition and Feed Tech (2009) 9, 73-79.

Akinnusi FAO. 2001. Pre-mating and pre-partum concentration supplementation on the reproductive performance of WAD ewes in Abeokuta, Ogun State. Ph.D Thesis. Dept. of Anim. Sci. University of Ibadan, Oyo State, Nigeria.

A.O.A.C. 1990. Official Method of Analysis. Association of Official Analytical Chemist Inc. $15^{\mathrm{TM}} \mathrm{Ed}$. Washington.

Ashworth CJ. 1994. Nutritional factors related to embryonic mortality in the domesticated species. In: Embryonic mortality in domestic species. Eds R.D Geisert and M.T Zary. CRC Press. pp 83-199

Annor SY, Kagya-Agyemang JK, Abbam JEY, Oppong SK, Agoe IM. 2008. Growth performance of grasscutter (Thryonomys swinderianus) eating leaf and stem fractions of guinea grass (Panicum maximum). Livestock Research for Rural Development 20(8).

Ayodele IA, Meduna AJ (2007). Essentials of grasscutter farming. Hope Publications Ltd., Ibadan. 66 pp.

Baumont R, Prache S, Meuret M, Morand-Fehr P. 2000. How forage characteristics influence behaviour and intake in small ruminants: A review. Livest Prod Sci 64, 15-28. http://dx.doi.org/10.1016/S0301-6226(00)00172-X

Duncan BD. 1955. Multiple Range Test and Multiple F-test, Biometrics 11, 1-42. http://dx.doi.org/10.2307/3001478

Heath E, Olusanya S. 1987. Anatomy and Physiology of Tropical Livestock. Longman Scientific and Technical 138.

Hurwitz S, Sklan D, Bartov I.1978. New formal approaches to the determination of energy and amino acid requirements of chicks. Poult Sci 57, 197-205. http://dx.doi.org/10.3382/ps.0570197 
Karikari PK, Nyameasem JK. 2009. Productive Performance and Carcass Characteristics of Captive Grasscutters (Thryonomys swinderianus) Fed Concentrate Diets Containing Varying Levels of Guinea Grass. World Applied Sci J 6 (4), 557-563.

Meduna AJ. 2000. Study on cane rat (Thryonomys swinderianus) management tecniques development in Nigeria. A Thesis submitted to the Department of Wildlife and Fisheries Management, Faculty of Agriculture and Forestry, University of Ibadan, Nigeria.

Minson DJ. 1982. The chemical composition and nutritive value of tropical grass. Tropical grasses. Skerma PJ. Ed. Rome: FAO 167-182.

National Research Council (NRC) 1991. Micro-livestock: Little known (grasscutter) animals with promising economic future. Xvii x 449 (Viet Meyer Noel Ed.). National Academy Press, Washington, D.C.

Obi O O, Omole AJ, Ajasin FO, Tewe OO. 2008. Nutritive potentials of four conventional forages fed to growing grasscutter (Thryonomys swinderianus). Livestock Research for Rural Development 20 (11).

Odunaiya O, Akinnusi FAO. 2008. Effects of some cheap locally available feeding materials on the growth performance of edible land snail (Achatina achatina. L). (ed) O.A Adeyemi. Proceeding 33rd Annual Conf. of Nig Soc for Anim Prod. 126-128 pp.

Ogunjinmi AA, Meduna AJ, Ajani MO, Osunsina 100, Ogunjobi JA. 2007. Preliminary observations on the rearing of crocodiles in captivity at Federal College of Wildlife Management, New Bussa. Niger State, Nigeria. Trop J Anim Sci (10) 1-2 pp. 129-133.

Ogunjobi JA. Meduna AJ, Inah, El. Oyeleke OO , Ogunjinmi AA. 2007. Assessment of the common forages and feed stuffs available to cane rats on farms in Oyo State, Nigeria. Trop J Anim Sci (10) 1-2, 161-165.

Ogunjobi JA. 2008. Scio-ecological assessment of cane rat (Thryonomys swinderianus Temminck, 1827) farming in Oyo State Nigeria. Master of Wildlife Management (MWM) Dissertation, University of Agriculture Abeokuta, Ogun State, Nigeria. (Unpublished)

Onwudike OC.1995. Use of the legumes tree crops Gliricidia sepium and Leucaena leuocephala as green feeds for growing rabbits. Animal Feed Science and Technology 51, 153 - 163. http://dx.doi.org/10.1016/0377-8401(94)00643-N

Onadeko S.A, Meduna AJ, Shotuyo ALA. 1998. Some Indicators of the Ecological Impact of Deforestation on Wildlife Conservation in the Savanna, Nigeria. Journal of Tropical Ethno-Forestry 1, 71-80.

Onadeko SA. 1996. Body Weight Changes, Morphometry and Attainment of Puberty in Captive-Bred Grasscutter (Thryonomys swinderianus Temminck). Tropical Journal of Animal Science 2(1), 195-201.

Redford KH, Godshalk P, Asher P. 1995. What about the wild animals?. Wild animal species in community forestry in the tropics. Community Forestry. Note 13. Food and Agricultural Organization of the United Nations, Rome.

SAS 1999. S.A.S. User's Guide. Statistical Analysis System Institute, Inc. Cary, N.C.

Schmelzer GH. 1996. Review of Pennisetum section Brevivalvula (Poaceae). Euphytica 97, 1-20. http://dx.doi.org/10.1023/A:1003077906928

Shiawoya EL, Tsado DN. 2011. Forage and Fodder Crop Production in Nigeria. World J Life Sci and Med Res 1(4), 8893.

Surujally RS. 1975. Game farming is a reality. Unasylva 29, 13-15.

Warwick C. 1987. Effect of captivity on the Ethology and Psychology of Reptiles. Herpetoculturist 1(2), 10-12. 